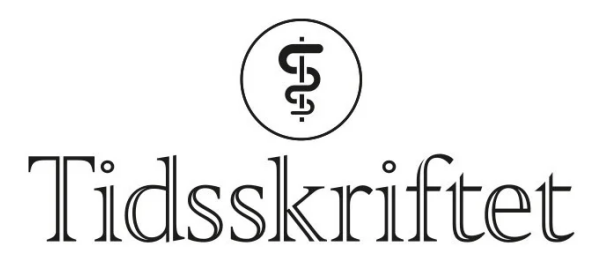

DEN NORSKE LEGEFORENING

\title{
Vaksiner er ingen premie
}

DEBATT

JOAR RØKKE FYSTRO

j.r.fystro@medisin.uio.no

Joar Røkke Fystro er stipendiat ved Avdeling for helseledelse og helseøkonomi, Institutt for helse og samfunn, Universitetet i Oslo.

Forfatter har fylt ut ICMJE-skjemaet og oppgir ingen interessekonflikter.

\section{Skal fortidens feil spille en rolle i prioriteringen av helsehjelp? Det gir i så fall debatten om prioritering av helseressurser en helt ny dimensjon.}

Får Oslo flere vaksiner på grunn av smittetrykket, er det en «slags omvendt premiering» (11). Det var ordfører i Molde, Torgeir Dahl, som målbar dette synspunktet i en diskusjon om skjevfordeling av covid-19-vaksiner ut fra hvor smittetrykket er høyest. Begrunnelsen var at han er lite imponert over hva Oslo har fått til. Smittetrykket viser ifølge Dahl at hovedstaden har gjort en for dårlig jobb.

Argumentet er følgelig todelt. For det første hevder han at hovedstadens håndtering av pandemien ikke holder mål. For det andre sier han at på grunn av den sviktende håndteringen, vil det bli en «omvendt premiering» dersom Oslo får forholdsvis flere vaksiner.

\section{Hva betyr «omvendt premiering»?}

Det betyr at Oslo kanskje ikke skal få flere vaksiner (geografisk prioritering) på grunn av jobben politisk ledelse og/eller folket har gjort. Med andre ord tillegges fortidens valg og potensielle feil betydning når geografisk prioritering skal vurderes. Hittil i pandemien har vi vært opptatt av å beskytte dem som trenger det mest, forebygge overbelastning av helsevesenet og få samfunnet raskest mulig på bena igjen ((ㄹ), s. 14). Vektleggingen av ansvar er en ny dimensjon og begrunnes ikke i nytte, men må heller forstås som en form for rettferdighet: Oslo fortjener ikke flere vaksiner på grunn av deres håndtering av pandemien.

"Vektleggingen av ansvar er en ny dimensjon og begrunnes ikke i nytte, men må heller forstås som en form for rettferdighet»

\section{En trend i tiden}


Det styrkede fokuset på (personlig) ansvar i helsespørsmål synes å ha minst to årsaker (3). På den ene siden har utbredelsen av livsstilssykdommer satt individets atferd under lupen. På den andre siden har ansvarsdimensjonen blitt mer og mer fremtredende i politisk filosofi. At de som er dårligere stilt og ikke kan stilles til ansvar for sitt uføre skal få hjelp, er ukontroversielt. Spørsmålet er derimot om de som mer eller mindre kan takke seg selv for elendigheten har krav på samfunnets hjelp, eller i det minste om de har en dårligere sak for å få slik hjelp. Hvorvidt personlig ansvar bør telle i prioritering av helsehjelp, har utløst akademisk debatt (4.) og vært diskutert i offentlige utvalg (5).

\section{Hva skal vi svare?}

Svarer du at Oslo ikke har gjort en dårlig jobb, eller at de ikke kan stilles til ansvar for smittetrykket, forholder du deg til påstanden om hovedstadens håndtering av pandemien. Du tar ikke aktivt stilling til premisset om at ansvar i det hele tatt er relevant når vaksiner skal fordeles. Vi har alle behov for å svare på anklager. Men lar vi antakelsen om at ansvar skal telle i prioriteringen av helsehjelp være i fred, kan konsekvensen være at den blir en sannhet vi ikke stiller spørsmål ved.

\section{LITTERATUR}

1. Lode SC. Molde-ordfører om smitten: - Lite imponert over hva Oslo har fått til. VG 28.2.2021. https://www.vg.no/nyheter/innenriks/i/1BRkpK/molde-ordfoerer-om-smitten-lite-imponert-over-hvaoslo-har-faatt-til Lest 15.3.2021.

2. Feiring E, Førde R, Holm S et al. Råd om prioriterte grupper for koronavaksinasjon i Norge. Oslo: Folkehelseinstituttet, 2020. https://www.fhi.no/publ/2020/rad-om-prioriterte-grupper-forkoronavaksinasjon-i-norge/ Lest 15.3.2021.

3. Bognar G. The mismarriage of personal responsibility and health. Camb QHealthc Ethics 2020; 29: 196-204. [PubMed][CrossRef]

4. Sharkey K, Gillam L. Should patients with self-inflicted illness receive lower priority in access to healthcare resources? Mapping out the debate. J Med Ethics 2010;36: 661-5. [PubMed][CrossRef]

5. Traina G, Feiring E. Priority setting and personal health responsibility: an analysis of Norwegian key policy documents. J Med Ethics 2020; 46: medethics-2019-105612. [PubMed][CrossRef]

Publisert: 14. april 2021. Tidsskr Nor Legeforen. DOI: 10.4045/tidsskr.21.0206

(C) Tidsskrift for Den norske legeforening 2023. Lastet ned fra tidsskriftet.no 26. april 2023. 